\title{
Perlawanan Petani Garam Madura Terhadap Monopoli Dagang Kolonial Belanda: Tinjauan Historis
}

\author{
Desi Illa Mufliha ${ }^{1} \mid$ Aisah Nur Khasanah ${ }^{2} \mid$ Hasbi Ash Siddiqy ${ }^{3} \mid$ Achmad Lutfi $^{4} \mid$ Dwi Susanto ${ }^{5}$
}

\author{
${ }^{1}$ Program Studi Sejarah \\ Peradaban Islam \\ UIN Sunan Ampel, Surabaya \\ ${ }^{2}$ Program Studi Sejarah \\ Peradaban Islam \\ UIN Sunan Ampel, Surabaya \\ ${ }^{3}$ Program Studi Sejarah \\ Peradaban Islam \\ UIN Sunan Ampel, Surabaya \\ ${ }^{4}$ Program Studi Sejarah \\ Peradaban Islam \\ UIN Sunan Ampel, Surabaya \\ ${ }^{5}$ Program Studi Sejarah \\ Peradaban Islam \\ UIN Sunan Ampel, Surabaya
}

Correspondence:

Desi Illa Mufliha

Program Studi Sejarah

Peradaban Islam

UIN Sunan Ampel, Surabaya

desiillamufliha@gmail.com

\section{Article History:}

Received 2 December 2021

Revised 21 January 2022

Accepted 28 January 2022

\begin{abstract}
Sumenep is one of the salt-producing cities in Indonesias. In the pre-colonial period, salt had become an essential commodity in trade. Therefore, the Dutch colonial belonged to Madura and implemented a monopoly system on the salt trade. The applied salt monopoly system has an impact on salt farmers in Madura. Madurese salt farmers then fought against the Dutch colonials, although this resistance was finally quelled. This study aimed to find out and understand the motives of the resistance of Madura salt farmers against the Dutch colonials in Sumenep. This study is a literature review with a qualitative descriptive method. This research includes first, the history of the entry of the Dutch colonial into Sumenep; second, the process of resistance by Madura salt farmers against the Dutch colonial monopoly; third, the impact of the Dutch colonial salt monopoly system on salt farmers in Madura. In general, farmers fought back because the Dutch colonial monopoly system harmed the salt farmers, both as landowners and workers in the salt fields.
\end{abstract}

Keywords: Salt farmers, monopoly, Dutch colonial, Sumenep, Madura

\section{Abstrak}

Sumenep merupakan salah satu kabupaten penghasil garam berkualitas di Indonesoa. Pada masa pra kolonial garam telah menjadi komoditi penting dalam perdagangan Nusantara. Oleh sebab itu, kolonial Belanda kemudian milirik Madura dan menerapkan sistem monopoli dalam perdagangan garam Nusantara. Sistem monopoli garam dalam perdagangan garam menimbulkan dampak bagi petani garam di Madura. Petani garam Madura lantas melakukan perlawanan terhadap kolonial Belanda, meskipun resistensi mereka dapat dipadamkan. Tujuan penelitian ini untuk mengetahui dan memahami motif perlawanan petani garam Madura terhadap kolonial Belanda di Sumenep. Kajian ini merupakan telaah pustaka dengan metode kualitatif-deskriptif. Penelitian ini meliputi, (1) sejarah masuknya kolonial Belanda ke Sumenep; (2) proses perlawanan petani garam Madura atas monopoli kolonial Belanda; (3) dampak sistem monopoli garam oleh kolonial Belanda terhadap petani garam di Madura. Secara umum, petani melakukan perlawanan karena dilatarbelakangi penerapan sistem monopoli kolonial yang merugikan pihak petani garam, baik sebagai pemilik lahan maupun sebagai pekerja di lahan garam.

Kata Kunci: Petani garam, monopoli, kolonial Belanda, Sumenep, Madura 


\section{Pendahuluan}

Motif kedatangan pelancong asal Belanda ke wilayah Nusantara mulanya dilatarbelakangi kepentingan niaga. Dari praktik perdagangan hingga monopoli serta blokade pelayaran, pihak Belanda yang direpresentasikan oleh Vereenigde Oost Indische Compagnie (VOC) beralih melakukan praktik penguasaan wilayah (Ricklefs, 2011). Sehingga bisa dipahami mengapa pihak pribumi kemudian melakukan perlawanan terhadap praktik kalonialisme Belanda.

Cerita perlawanan terhadap pemerintah Belanda yang notabene dilakukan penduduk desa tidak hanya tercatat dalam dokumen-dokumen resmi yang merekam memori kolektif suatu kondisi masyarakat Nusantara. Dalam khazanah kesusastraan jamak ditemukan epos perlawanan penduduk desa yang umumnya tidak terdidik dalam melawan kolonialisme Belanda, misalnya Max Havelaar yang ditulis Eduard Douwes Dekker atau Sitti Nurbaya gubahan Marah Roesli (Atikurrahman \& Ilma, 2021). Kisah perlawanan dalam dua novel tersebut berbeda dengan model resistensi kalangan terdidik seperti tergambar dalam Bumi Manusia, Hikayat Kadiroen, Student Hidjo dan sebagainya.

Kisah perlawanan massal terhadap pihak kolonial Belanda umumnya dipicu oleh monopoli perdagangan, intriks politik penguasa lokal, hingga pajak. Sedangkan dalam konteks Madura, yang menjadi konteks dari kajian ini, selain persoalan pajak motif perlawanan massal penduduk pulau garam dilatarbelakangi monopoli perdagangan garam.

Selain menjadi identitas kultural, garam bagi penduduk Madura adalah lambang kemakmuran. Madura seringkali disebut pulau garam. Garam yang dihasilkan oleh petani setempat memiliki kualitas unggul dibandingkan wilayah lain di Nusantara. Pulau Madura terdiri dari empat kabupaten yakni Bangkalan di bagian barat pulau,
Sampang dan Pamekasan di tengah, dan Sumenep di timur. Sampang, Pamekasan, dan Sumenep adalah sentra penghasil garam. Namun kabupaten terakhir merupakan penghasil utama garam di Madura. Belanda telah melakukan praktik monopoli garam di Madura sejak 1882 (Parwoto, 2018).

Garam Madura memiliki nilai ekonomi tinggi karena kualitas garam yang masuk kategori unggul. Secara geografis, Madura terletak pada $113^{0}$ dan $114^{0}$ Bujur Timur dan $7^{0}$ lintang selatan dengan panjang $160 \mathrm{~km}$ dan lebar $40 \mathrm{~km}$. Pulau ini dipisahkan selat dangkal dengan iklim yang dominan panas. Kondisi alam tersebut turut mendukung dan menguntungkan Madura di balik hasil garam berkualitas yang dihasilkan (Rahayu, 2016).

Pada bidang politik, Madura tidak pernah menjadi kesatuan wilayah. Sebelum diduduki Kolonial, di Madura telah berdiri beberapa kerajan lokal yang saling bersaing (Ricklefs, 2011). Kerajaan-kerajaan di Madura terafiliasi dan sangat bergantung pada eksistensi kerajan-kerajaan besar di Jawa (de Jonge, 1989). Setelah Pakubuwono I menyerahkan Sumenep, pihak kolonial berusaha menancapkan kekuasaanya di daerah jajahan. Pada 1705 Mataram menyerahkan sebagian wilayah Madura pada pihak VOC. Disusul tahun 1743 Pakubuwana II kembali mewariskan wilayah lain di Madura sehinga pula Madura berada dalam kendali Belanda (de Graaf, 1987; Kartodirdjo, 1973; Ricklefs, 2011; Rifai, 2007).

Kolonialisme Belanda di Madura memberikan dampak yang signifikan terutama pada wilayah Madura Timur, yaitu Sumenep. Kota keraton yang berada di Sumenep mulai disusupi dengan unsurunsur asing. VOC lantas menjadikan Sumenep sebagai Kota Hindia Lama (Oud Indische Stad). Kemudian, Madura termasuk Sumenep menjadi bagian Pemerintahan Kolonial Belanda setelah pembubaran VOC pada 1799. Sumenep di bawah Pemerintahan Kolonial Belanda mengalami 
kemajuan yang pesat di berbagai bidang termasuk di dalamnya bidang ekonomi (Mahmudah, 2018).

Pulau Madura merupakan pulau yang tidak begitu subur dan kurang cocok untuk dijadikan sebagai wilayah pertanian (Rahayu, 2016). Oleh sebab itu jenis pertanian harus disesuaikan dengan kondisi geografis Madura. Pertanian menjadi salah satu mata pencaharian masyarakat Madura selain berdagang dan nelayan. VOC memberlakukan sistem pajak bagi wilayah-wilayah yang memiliki pasokan minyak kelapa, garam, dan asam secara teratur (Wisnu, 2019). Karena itu banyak orang Madura yang melakukan migrasi ke berbagai wilayah terutama di Jawa Timur (Syah \& Purwanto, 2015). Selanjutnya, pada abad ke-19 Pulau Madura mengalami peningkatan dalam industri pergaraman yang menjadikan Madura sebagai pemasok utama garam nasional (Parwoto, 2018; Syafi'i, 2013).

Sebagai sebuah komoditas, garam telah diperdagangkan sebelum sebelum kedatangan VOC. Pada masa pemerintah lokal Madura tambak garam telah digarap dengan menggunakan sistem sewa. Hasil dari perdagangan garam tersebut membuka sirkulasi uang yang beredar di Madura. Dapat dikatakan penjualan garam setingkat dengan pewarisan (Kuntowijoyo, 1985). Oleh sebab itu, VOC melihat perdagangan garam sebagai niaga yang menjanjikan. VOC lantas menerapkan sistem lisensi pajak, yakni menarik keuntungan dari perdagangan garam. Sistem itu diterapkan VOC karena kurang dalam pengelolaan administrasi dan sumber daya alam. Sehingga sistem dagang tersebut diterapkan untuk meningkatkan keuntungan dan berhasil mengalami kenaikan (Wahid, 2015).

Pada masa pendudukan VOC, daerah yang dikenal dengan daerah garam disebut dengan zoutnegorizen, dan ketika beralih pada pemerintah Belanda disebut zoutlanden. Karena garam memiliki nilai ekonomi yang tinggi maka sejak 1915 pemerintahan membentuk dinas regie. Dalam produksinya mereka menggunakan cara pabrikan yang disebut dengan garam briket. Garam briket adalah garam pasir yang dicetak dalam bentuk kubus dengan ukuran tertentu seperti $1 \mathrm{~kg}, 10 \mathrm{~kg}, 15 \mathrm{~kg}$, dan $25 \mathrm{~kg}$ (Parwoto, 2018).

Salah satu wilayah penghasil garam di Pulau Madura adalah Sumenep. Sumenep salah satu kota dari empat kota kabupaten yang berada di Madura. Letaknya berada di ujung timur pulau tersebut. Kata Sumenep berasal dari kata Soengennep. Masyarakat pedesaan menyebutnya dengan Soengennep. Sedangkan masyarakat yang tinggal di pusat kota lebih akrab dengan kata Sumenep. Penggunaan huruf 'O' lebih nyaman dan lebih cocok dengan logat orang Madura (Tim Dinas Pariwisata dan Kebudayaan, 2003). Kata Songennep diubah ke Sumenep ketika abad XVIII oleh Belanda (Atikurrahman, 2008).

Pendapatan yang diperoleh dari penjualan garam ternyata melebihi pendapatan opium. Pendapatan yang diperoleh dengan menggunakan sistem monopoli ini cukup tinggi dan stabil. Oleh sebab itu, penjualan garam menjadi komoditas yang bisa diandalkan bahkan mampu untuk menopang keuangan pemerintah kolonial Belanda (Wahid, 2015). Seperti dinarasikan Pramoedya dalam Bumi Manusia, bahwa kolonial tidak lain untuk kehendak, kepentingan pasar dan memenuhi keberlangsungan dan modal di Eropa (Toer, 2002). Keuntungan bersih yang didapatkan setiap tahunnya (1912-1920) ratarata lebih dari 9 juta gulden (Parwoto, 2018).

\begin{tabular}{|l|l|}
\hline Tahun & Jumlah Keuntungan \\
\hline 1916 & 9.220 .205 .09 \\
\hline 1917 & 9.958 .217 .69 \\
\hline 1918 & 10.274 .753 .37 \\
\hline 1919 & 10.083 .605 .29 \\
\hline 1920 & 9.304 .698 .00 \\
\hline
\end{tabular}

Sistem monopoli garam menimbulkan gejolak yang bermuara pada konflik yang melibatkan 
pemilik lahan tambak garam, penggarap garam, dan pihak-pihak lainnya, termasuk pemerintah kolonial Belanda. Beberapa aksi dilakukan oleh petani garam untuk memprotes monopoli garam di Madura (de Jonge, 2011). Sistem monopoli dilakukan dengan cara memborong perdagangan garam dan mengawasi setiap kegiatan produksinya. Penerapan sistem monopoli tetap dijalankan pasca Belanda angkat kaki dari Indonesia. Hal ini menyebabkan konflik lahan garam masih terjadi hingga abad XX (Yulinda, et al., 2014). Berdasarkan penjabaran di atas, tulisan ini mengajukan rumusan masalah sebagai berikut; bagaimana sejarah masuknya Belanda di Sumenep? Bagaimana perlawanan petani garam terhadap monopoli pemerintah kolonial Belanda di Sumenep? Apakah dampak sistem monopoli garam di Sumenep?

Penelitian ini merupakan kajian pustaka dengan menggunakan metode kualitatif deskriptif. Metode kualitatif digunakan sebagai prosedur penelitian untuk memberikan data deskriptif berupa tulisan yang disusun secara sistematis. Data yang diperoleh dalam penelitian ini diperoleh dengan cara menelaah buku, jurnal, catatan, serta berbagai laporan resmi lainnya (Sari \& Asmendri, 2018). Penelitian ini menggunakan pendekatan historis untuk menguak informasi-informasi yang berhubungan dengan sistem monopoli garam di Sumenep. Lebih lanjut, penelitian ini menggunakan pendekatan statistikdeskriptif untuk memaparkan data-data kuantitatif seputar industri garam di Sumenep, Madura.

\section{Hasil dan Pembahasan}

\section{Sejarah Masuknya Belanda di Sumenep}

Sejak awal kedatangan VOC di Nusantara, pihak Belanda cenderung ikut campur dalam urusan internal kerajaan lokal. Tujuannya adalah monopoli niaga sehingga mereka mereka mendapatkan harga yang rendah dan memaksimalkan laba dari komoditas yang dijual di pasar Eropa. Oleh sebab itu, VOC sangat sigap untuk menghancurkan pihakpihak yang mengganggu kepentingan niaga mereka.

Dari sistem monopoli dagang, pihak Belanda beralih pada skema pendudukan wilayah koloni sejak awal abad XIX. Di akhir abad XVIII, VOC bangkrut. Selain konflik internal kerajaan lokal di Nusantara, kerajaan Belanda terlibat konflik dengan Perancis yang menyebabkan pihak kerajaan terlilit utang yang sangat mempengaruhi kas negara. Maka sejak saat itu, pihak Belanda mengubah strategi dari perdagangan ke pendudukan wilayah koloni. Dengan menduduki wilayah-wilayah Nusantara yang kaya akan bahan baku pemerintah kolonial Belanda dapat lebih leluasa memperoleh laba dari aktivitas dagang mereka di pasar Eropa. Dengan sistem monopoli dan pajak, maka perlahan kas kerajaan mulai pulih dan stabil. Terutama setelah van den Bosh memberlakukan cultuur stelsel pasca Perang Jawa (1825-1830), pihak Belanda menimati keuntungan yang berlipat ganda atas pendudukan terhadap wilayah-wilayah Nusantara (Carey, 2008; Ricklefs, 2011).

Awalnya pemerintah kolonial Belanda berfokus pada wilayah Jawa dan Sunda. Setelahnya, mereka mulai menduduki Sumatera, Jawa, Madura, Bali dan sekitarnya. Sejak masa kejayaan VOC, pihak Belanda telah melakukan perjanjian dengan daerah-daerah yang ditaklukkan militer Belanda. Seringkali pihak VOC memberlakukan pembaruan perjanjianperjanjian dagang secara sepihak atas wilayah taklukkan. Mereka juga terkadang memberikan 'pemerintahan otonom' kepada wilayah yang ditaklukkan. Artinya, penguasa pribumi diberikan kebebasan dalam bertindak di wilayah mereka namun dengan syarat-syarat yang telah ditentukan pihak Belanda (de Jonge, 2011).

Sejak Mataram dan VOC mengadakan perjanjian pada 1705, Sumenep sepenuhnya jatuh dalam kekuasaan kolonial. Awlanya pihak Belanda memberikan status 'pemerintahan otonom' kepada 
Sumenep. Sepanjang abad XVIII pihak Belanda melakukan pembaharuan kontrak sebanyak tiga kali. Tujuan VOC untuk menjaga dan memastikan Sumenep tidak mengganggu kegiatan dagang VOC (Rahayu, 2016).

Ketika Inggris berhasil menduduki Hindia Belanda pada 1811, Sumenep berhasil ditaklukkan setelah melewati perlawanan yang sengit. Jendral Inggris, Raffles menghapus pajak kontingen dan berhasil meningkatkan pengaruhnya ke desa-desa setempat dengan memangkas kekuasaan regen, memperkenal pajak takan, dan memperbanyak pejabat Eropa. Di bawah kepemimpinan Raffles, Madura mendapatkan pengecualian. Jendral Inggris tersebut menciptakan hubungan baik dengan regen baru Sumenep serta memberikan gelar panembahan pada 1815 (Raffles, 2017).

Pada konvensi London, kerajaan Belanda menginginkan agar pihak Inggris mengembalikan wilayah Nusantara ke pihak Belanda. Maka setelah proses pengembalian selesai, pemerintah kolonial Belanda melakukan pembaharuan kontrak dan perjanjian atas wilayah Madura, termasuk Sumenep. Pada abad XIX pihak Belanda membuat tiga kontrak baru dengan Sumenep. Kontrak tersebut berbeda dari kontrak sebelumnya, dalam perjanjian baru tersebut terdapat pelbagai tambahan. Konsekuensi dari pembaharuan perjanjian tersebut pihak pemerintah Belanda menunjukkan peningkatan kekuasaan dalam masalah-masalah lokal. Meskipun Sumenep tetap berstatus sebagai 'pemerintahan otonom'.

\section{Perlawanan Petani Garam Terhadap Sistem Monopoli Kolonial Belanda di Sumenep}

Sejak abad XVIII VOC telah menetapkan landasan monopoli garam. Perusahaan dagang Belanda tersebut memborong hasil panen garam dan mengawasi tahap produksinya. Garam merupakan komoditi yang menjanjikan dan salah satu hasil industri terpenting di Jawa sehingga memungkinkan VOC meraup keuntungan yang besar (de Jonge, 2011).

Terdapat tiga penguasaan koonial di Madura; pertama, VOC menjadi perusahaan dagang yang melihat pentingnya intervensi ke dalam masalah internal kerajaan. Hal tersebut tentunya memudahkan mereka mendapatkan hasil produksi; kedua, VOC memandang Madura sebagai salah satu tameng atau kekuatan yang patut dipertimbangkan dan melakukan perimbangan dengan kekuatan Mataram; ketiga, Madura menjadi pemberi hasil upeti yang penting bagi VOC melalui produksi garam (Parwoto \& Kartodirdjo, 1996). Sedangkan dari praktik monopoli garam yang diterapkan VOC, nilai ekonomis garam yang mempengaruhi situasi pulau Madura sebagai produsen utama garam (Ricklefs, 2011).

Dibandingkan garam dari daerah-daerah lain, garam Madura memiliki kualitas yang sangat baik karena konfigurasi Madura terbentuk dari bertanah kapur serta memiliki kemarau yang lebih lama. Garam Madura lantas dipasok ke wilayah-wilayah kekuasaan kolonial Belanda di Indonesia. Ketika terjadi perpindahan kekuasan dari Belanda ke Inggris (1811-1816), monopoli garam dilaksanakan lebih ketat di Madura dan Jawa. Hal tersebut demi memberantas penyelewengan dan meningkatkan keuntungan. Artinya, seluruh sirkulasi produksi garam menjadi milik pemerintah. Sistem yang berlaku bagi para petani garam adalah mereka harus mengirim hasil panen garam ke gudanggudang milik Belanda dengan harga yang telah ditentukan Jika membangkang, para petani akan dihukum dengan berat (de Jonge, 2011).

Di samping itu, pihak kolonial Belanda juga mengeluarkan dekrit untuk mencegah munculnya peraturan-peraturan aneh. Maka "peraturanperaturan untuk memastikan monopoli garam" secara resmi dimaklumatkan pada Staad van 
Nederlandsch-Indie. Dengan dekrit tersebut posisi pemerintah kolonial semakin kuat (de Jonge, 2011). Selain itu, petani garam hanya bisa melakukan produksi garam jika mereka memiliki lisensi dari pemerintah. Keuntungan yang didapatkan dari hasil sistem monopoli garam ini digunakan untuk kepentingan pemerintahan Kolonial Belanda, dengan rata-rata lebih dari 9 juta gulden (Parwoto, 2018). Seperti dinarasikan oleh Marah Roesli dalam Sitti Nurbaya, di Sumenep pihak pemerintah juga menerapkan belasting seperti pada penduduk Melayu di Minangkabau. Mereka meminta uang Belasting untuk keperluan pemerintah dalam menjalankan roda pemerintahannya di Hindia Belanda (Atikurrahman et al., 2021; Roesli, 2011).

Garam berkembang dari 'urusan pemerintah' menjadi 'usaha pemerintah'. Kalianget, sebuah kota kecil di pesisir Sumenep, berubah menjadi sibuk setelah dijadikan kawasan pabrik, perkantoran, dan perumahan para pekerja Eropa. Orang-orang Eropa tersebut dipekerjakan untuk mengawasi produksi garam serta mengatur pengeluaran dan pemasukan penjualan garam. Pihak pemerintah kolonial juga membuka jalur kereta api dari Kalianget ke Kamal. Sedangkan pelabuhan Kalianget berfungsi sebagai bandar kapal khusus pengangkut garam yang berlayar ke seantero Nusantara (de Jonge, 2011).

Monopoli garam yang dilakukan pengusaha dan penguasa menyebabkan produksi garam masuk dalam penetrasi sistem kapitalisme. Dalam sistem kapitalisme tersebut status sosial petani garam menjadi kelas dasar dalam hierarki sosial. Para petani garam ditempatkan sebagai tenaga penggarap dan upahan dalam sirkulasi produksi garam. Situasi tersebut mendorong munculnya resistensi berupa protes massal yang terjadi pada awal abad XX. Sedangkan pada abad sebelumnya protes dari pihak petani garam hanya dilakukan secara individu dan sporadis (Rochwulaningsih, 2007).
Monopoli garam yang dilakukan oleh pemerintah kolonial memicu migrasi dari sebagian penduduk lokal ke pulau Jawa. Ditambah lagi beban pajak yang harus mereka tanggung. Oleh sebab itu, pada musim panen garam pemerintah menempatkan polisipolisi garam untuk mengamankan gudang garam milik pemerintah dari sabotase penduduk sebagai bentuk protes terhadap kesewenang-wenangan pemerintah (de Jonge, 2011).

Pada 1934 dan 1936 sempat erjadi benturan keras antara pemerintah dan petani garam di Sumenep. Hal ini dipicu tambak-tambak garam milik penduduk diambil alih oleh pejabat garam pemerintah. Sedangkan pemilik tambak hanya diberi kompensasi yang tidak sepadan. Selama keributan tersebut banyak petani dan pengunjuk rasa yang ditangkap dan dipenjara. Karena tidak memiliki sarana yang mencukupi untuk melakukan perlawanan jangka panjang, maka protes massal yang dilakukan petani garam di Sumenep dengan cepat dapat dipadamkan oleh pemerintah kolonial Belanda.

\section{Dampak Sistem Monopoli Garam Kolonial}

\section{Belanda di Sumenep}

Kala itu Sumenep ditetapkan sebagai wilayah penghasil garam terbaik di Madura dibandingkan Pamekasan dan Sampang. Sentra produksi garam wilayah Sumenep terletak di sebelah utara pusat kota yang berbatasan langsung dengan Kalianget dan di sebelah selatan dengan Tanjung. Sebuah pabrik garam briket di Kalianget diakui sebagai salah satu pabrik garam modern pertama di Madura. Pabrik garam briket Kalianget dibangun dengan sistem canggih oleh pemerintah koloni kala itu. Tak hanya membangun sebuah pabrik garam yang didesain dengan arsitektur yang mapan, pada 1909 pihak Belanda juga menyiapkan banyak gudang khusus penyimpanan hasil industri yang telah dibentuk menjadi brisket garam. Total gudang 
yang dibangun pemerintah berjumlah 167 gudang garam dan tersebar di beberapa wilayah di Madura. Sedangkan di Sumenep sendiri terdapat 85 gudang garam.

Dari tahun ke tahun industri garam di Madura terus melakukan pengembangan perusahaan. Pada 1912 perusahan garam di Madura membuka firma pelayaran sendiri. Sehingga produksi garam terusmenerus ditingkatkan hingga mencapai puncak keemasannya pada 1918. Pemerintah Belana ikut andil dalam pengembangan produksi garam di Sumenep dengan cara melakukan ekspansi dengan membuka banyak ladang garam di Nambakor Barat dan Gersik Putih, Sumenep dari 1922 hingga 1925 (Mahmudah, 2018).

Masyarakat yang memproduksi garam diklasifikasikan sebagai pemilik lahan dan petani garam. Banyak pemilik lahan tidak mengelola lahan miliknya. Mereka bekerja sama dengan petani garam yang notabene buruh tani. Di Sumenep dan Pamekasan terdapat sistem "maro" (separuh) dalam ikatan kerja sama pengelolaan lahan. Dalam sistem maro hasil diproduksi dibagi dua antara pemilik dan pekerja. Sistem maro dalam pertanian garam tersebut dipraktikan oleh pemerintah Belanda untuk memonopoli produksi garam di Madura (Wisnu, 2019).

Monopoli melalui sistem maro menimbulkan reaksi dari pemilik dan petani garam terhadap pemerintah kolonial Belanda. Perasaan tidak puas petani garam diungkapkan dengan menghasilkan produk garam yang tidak berkualitas. Selain itu, petani juga melakukan aksi ngoret di ladang garam. Aksi ngoret adalah tindakan mengambil sisa-sisa hasil panen garam di ladang. Aksi ngoret umumnya dilakukan oleh para perempuan setempat yang berusia 25 hingga 40 tahun. Pelaku ngoret menggunakan peralatan sapu lidi kecil, serok, timba atau engkrak, dan karung. Sebagai bentuk perlawanan, aksi ngoret ini dapat didefinisikan sebagai "pencurian yang disamarkan" (Rochwulaningsih, 2016).

Sarekat Islam, salah satu organisasi berbasis niaga dan berideologi Islam, turut serta melakukan perlawanan atas tindakan pemerintah dalam monopoli perdagangan garam. Organisasi tersebut memiliki kemampuan menggerakkan massa di Madura demi membela kepentingan petani garam. Sarekat Islam menjadi mediator untuk menyampaikan tuntutan rakyat kepada pemerintah (Parwoto, 2018). Setelah kemerdekaan Indonesia, mula-mula sistem monopoli kolonial tetap dilanjutkan. Monopoli pertanian garam tidak terlalu sukses karena kekacauan pasca perang. Sejak 1959 sistem monopoli dalam pertanian garam mulai ditinggalkan hanya menjadi sisa peninggalan sistem kolonial. Lalu, pada perkembangan berikutnya (sekitar dekade 70-an) monopoli pergadangan garam kembali dilakukan pemerintah Orde Baru karena terjadi kelangkaan garam. Untuk menjamin ketersediaan garam maka pemerintah mengambil alih produksi dan penjualan garam di Madura (de Jonge, 2011).

Pasca kemerdekaan petani garam menghadapi masalah seperti pembebasan lahan yang dilakukan oleh Badan Usaha Milik Negara. PT. Garam sebagai representasi pemerintah bertugas untuk menjamin stok dan pasokan kebutuhan garam di Indonesia. Agenda tersebut menimbulkan penolakan oleh petani garam. Penolakan tersebut berujung pada penahanan petanigaram. Banyakhalyang dilakukan PT. Garam dalam memuluskan tujuannya, seperti mencabut sepihak surat yang diterbitkan Direktur Finek PN Garam No. 1222. Dokumen tersebut menyatakan bahwa pembebasan lahan harus terjadi atas kesepakatan bersama antara petani, pemilik, dan pemerintah dalam hal ini diwakili oleh PT. Garam. Pada 1985 para petani garam diusir dan diganti dengan pekerja baru. Hal tersebut menimbulkan reaksi. Para petani garam datang 
menemui Dewan Perwakilan Rakyat Republik Indonesia di Jakarta. Namun pihak legislatif dan eksekutif tidak memberikan kepastian sehingga pertani garam di Sumenep melakukan reclaiming. Gerakan reclaiming merupakan usaha petani garam untuk mendapatkan hak tanah mereka yang telah dirampas PT. Garam (Yulianda, 2014). Petani garam melihat praktik monopoli sebagai sebuah bentuk penindasan. Oleh sebab itu sejak masa kolonial mereka melakukan perlawanan terhadap intervensi pemerintah.

\section{Kesimpulan}

Garam sendiri merupakan komoditas penting dalam perekonomian Madura, terutama bagi masyarakat pesisir seperti Kalianget, Sumenep. Mata pencaharian penduduk setempat adalah pertanian garam.

Garam Sumenep Madura dikenal salah satu komoditas unggul. Kualitas garam Madura, utamanya Sumenep, disebut sebagai garam unggul sehingga menarik minat pihak pemerintah kolonial berdagang dan berinvestasi garam di Madura. Dengan mengandalkan sistem monopoli perdagangan garam, pihak Belanda menjadikan
Madura sebagai wilayah penyumbang devisa.

Penerapan praktik monopoli dalam perdagangan garam telah dilakukan sejak VOC terlibat intriks politik dalam kerajaan Mataram. Dengan monopoli dagang tersebut pihak kolonial Belanda berhasil mendapatkan keuntungan yang besar. Sistem monopoli garam menjadikan garam masuk ke dalam penetrasi kapitalisme. Sistem kapitalisme berdampak pada status para petani garam dalam sirkulasi produksi garam, yakni sebagai pekerja atau buruh garam.

Akhirnya sistem monopoli dalam perdagangan garam memicu berbagai reaksi sebagai ungkapan ketidakpuasan terhadap pemerintah. Perlawanan yang dilakukan mulai dari menghasilkan produk garam yang berkualitas rendah, sabotase, hingga aksi ngoret.

Selain monopoli garam yang berlaku sejak masa kolonial, masalah lain yang dihadapi petani garam adalah pembebasan lahan garam pasca kemerdekaan. PT Garam sebagai representasi pemerintah kerapkali merampas lahan milik petani garam setempat. Resistensi petani garam Madura dimulai sejak masa kolonial dan berlanjut di masa kemerdekaan.

\section{Daftar Pustaka}

Atikurrahman, M. (2008). Pergeseran Bentuk dan Makna Dalam Pengindonesiaan Nama-nama Tempat Berbahasa Madura di Kabupaten Pamekasan dan Kabupaten Sumenep Madura (Universitas Airlangga). Retrieved from https://repository.unair.ac.id/26991/

Atikurrahman, M., \& Ilma, A. A. (2021). Talkin Kematian Romantik Yang Berulang: Max Havelaar, Sitti Nurbaya, dan Kolonialisme. In E. Saparudin (Ed.), Manis Tapi Tragis: Kisah Saijah-Adinda dalam Max Havelaar (pp. 176-193). Retrieved from http://repository.uinsby.ac.id/id/eprint/1742/

Atikurrahman, M., Ilma, A. A., Dharma, L. A., Affanda, A. R., Ajizah, I., \& Firdaus, R. (2021). Sejarah Pemberontakan dalam Tiga Bab: Modernitas, Belasting, dan Kolonialisme dalam Sitti Nurbaya. SULUK: Jurnal Bahasa, Sastra, Dan Budaya, 3(1). https://doi.org/10.15642/suluk.2021.3.1.1-22

Carey, P. B. R. (2008). The Power of Prophecy: Prince Dipanagara and the End of an Old Order in Java, 17851855. https://doi.org/10.1163/9789067183031

de Graaf, H. J. (1987). Runtuhnya istana Mataram. Jakarta: Pustaka Utama Grafiti. 
de Jonge, H. (1989). Madura dalam Empat Zaman: Pedagang, Perkembangan Ekonomi, dan Islam (Suatu Studi Antropologi Ekonomi). Jakarta: Gramedia.

de Jonge, H. (2011). Garam Kekerasan dan Aduan Sapi. Yogyakarta: LKiS Yogyakarta.

Kartodirdjo, S. (1973). Sejarah Perlawanan-Perlawanan Terhadap Kolonialisme. Jakarta: Pusat Sejarah ABRI, Departemen Pertahanan Keamanan.

Kuntowijoyo, K. (1985). Agama, Islam, dan Politik: Gerakan-Gerakan Sarekat Islam Lokal di Madura 19131920. Jakarta: CV. Rajawali.

Mahmudah, I. (2018). Perkembangan Kota Sumenep pada Masa Pemerintahan Hindia Belanda Tahun 18831926. Avatara: E-Journal Pendidikan Sejarah, 6(3), 1-11. Retrieved from https://ejournal.unesa. ac.id/index.php/avatara/article/view/25784

Parwoto, P.-. (2018). Dampak Monopoli Garam di Madura pada Abad XX. MOZAIK: Jurnal Kajian Sejarah, 7(1). https://doi.org/10.21831/moz.v7i1.6182

Parwoto, P., \& Kartodirdjo, S. (1996). Monopoli Garam di Madura 1905-1920 (Universitas Gadjah Mada). Retrieved from http://etd.repository.ugm.ac.id/home/detail_pencarian/17924

Raffles, T. S. (2017). History of Java. Yogyakarta: Narasi. Yogyakarta: Narasi.

Rahayu, I. D. (2016). Pergeseran Kesultanan Sumenep Ke Tangan Voc Tahun 1624-1705. AVATARA, e-Journal Pendidikan Sejarah, 4(3). Retrieved from https://ejournal.unesa.ac.id/index.php/avatara/ article/view/16430

Ricklefs, M. C. (2011). Sejarah Indonesia Modern (D. Hardjowidjono, Ed.). Yogyakarta: Gadjah Mada University Press.

Rifai, M. A. (2007). Manusia Madura: Pembawaan, Perilaku, Etos Kerja, Penampilan, dan Pandangan Hidupnya seperti Dicitrakan Peribahasanya. Bekasi: Pilar Media.

Rochwulaningsih, Y. (2007). Petani Garam dalam Jeratan Kapitalisme : Analisis Kasus Petani Garam di Rembang, Jawa Tengah. Jurnal Masyarakat, Kebudayaan Dan Politik, 20(3). Retrieved from http://journal.unair.ac.id/filerPDF/Petani Garam dalam Jeratan Kapitalisme.pdf

Rochwulaningsih, Y. (2016). Senjata Kaum Lemah: Perlawanan Sehari-hari Petambak Garam. Jurnal Sejarah Citra Lekha, 1(2). https://doi.org/10.14710/jscl.v1i2.12765

Roesli, M. (2011). Sitti Nurbaya (Kasih Tak Sampai) (Empat Puluh Tujuh). Jakarta: Balai Pustaka.

Sari, M., \& Asmendri. (2018). Penelitian Kepustakaan (Library Research) dalam Penelitian Pendidikan IPA.

Penelitian Kepustakaan (Library Research) Dalam Penelitian Pendidikan IPA, 2(1). Retrieved from https://ejournal.uinib.ac.id/jurnal/index.php/naturalscience/article/view/1555

Syafi'i, I. (2013). Persaingan Pengangkutan Garam di Selat Madura Tahun 1924-1957. Jurnal Sejarah Citra Lekha, 17(1), 85-104. Retrieved from https://ejournal.undip.ac.id/index.php/cilekha/article/ view/6879

Syah, A. I., \& Purwanto, B. (2015). Migrasi Dan Ekonomi Masyarakat Madura Pada Akhir Masa Kolonial, 19001930an (Universitas Gadjah Mada). Retrieved from http://etd.repository.ugm.ac.id/penelitian/ detail/88359

Tim Dinas Pariwisata dan Kebudayaan. (2003). Sejarah Sumenep. Sumenep: PT. Mata Sumenep.

Toer, P. A. (2002). Bumi Manusia. Jakarta: Hasta Mitra. 
Wahid, A. (2015). Dari Sistem Lisensi ke Monopolitik Ekonomi Garam di Indonesia pada Masa Kolonial 18501940. Jurnal Jejak Nusantara, 3, 101-117. Retrieved from https://docplayer.info/114529484Dari-sistem-lisensi-ke-monopoli-politik-ekonomi-garam-di-indonesia-pada-masa-kolonialabdul-wahid-pengajar-universitas-gadjah-mada.html

Wisnu, W. (2019). Perekonomian Madura Pada Masa Kolonial: Mata Pencaharian, Usaha Garam, dan Transportasi. Retrieved from https://osf.io/edvxh/

Yulinda, N. A., Badriyanto, B. S., \& Parwata, P. (2014). Konflik Lahan Pergaraman di Kec. Gapura Kb. Sumenep Tahun 1975-1985. Jurnal Publik Budaya, 2(1), 69-77. Retrieved from https://jurnal.unej.ac.id/ index.php/PB/article/view/582 